Teologia i Moralność, volumen 12(2017), numer 2(22)

doi: 10.14746/tim.2017.22.2.20

\author{
JOANNA PICEWICZ \\ Akademia Ignatianum w Krakowie \\ Wydział Filozoficzny
}

\title{
Zagadnienie istoty szczęścia i sposobu jego osiągnięcia w traktacie $O$ życiu szczęśliwym Seneki Młodszego
}

W ujęciu filozoficznym pojęcie szczęścia jest niezwykle istotne i należy oczywiście do tych, które są jednocześnie wielce ważkie i dość niejasne. Filozofowie od wieków starają się zgłębić zagadnienie szczęścia. Powstało wiele koncepcji na ten temat. Początki rozważań o stanie będącym tematem niniejszego opracowania odnajdujemy w starożytnej Grecji ${ }^{1}$. Sokrates łączył szczęście z życiem cnotliwym (poznaniem dobra), które wyzwalało ludzkiego ducha, dając spełnienie, rozkosz oraz możliwość bycia pożytecznym i prawdziwym. Dzięki wiedzy (intelektualizm etyczny) można osiągnąć stan niezależności i wewnętrznej wolności, który wpisuje się w ogólny stan szczęśliwości². Według Platona szczęście to przede wszystkim powrót ludzkiego ducha do stanu pierwotnego życia, jakiego doświadczał w świecie idei. Szczęścia szukać należy także w filozofii oraz w sprawnie funkcjonującym państwie. Właśnie ono zapewnia odpowiednie wychowanie (paideia) swym obywatelom oraz zorganizuje sferę życia publicznego ${ }^{3}$. Zgodnie z etyką Arystotelesa szczęście można osiągnąć poprzez dążenie do najcenniejszych dóbr, jakimi są cnoty, z uwzględnieniem także dóbr podstawowych, jak: zdrowie, uroda, przyjaciele czy dobra materialne. Stagiryta uważał, że tylko człowiek zdolny do przyjaźni może doznać prawdziwego szczęścia, do którego skła-


sadnionego zadowolenia i satysfakcji z własnego życia, którego osiągnięcie było podstawowym celem każdego myślącego człowieka.

2 Platon, Eutydem, 280b-281e, thum. W. Witwicki, Dialogi, t. II, Kęty 2005, s. 204-205; por. także Diogenes Laertios, Żywoty i poglady słynnych filozofów, ks. II, 5, 18, tłum. I. Krońska, Warszawa 1982.

${ }^{3}$ Platon, Państwo, 540a-b, tłum. W. Witwicki, Kęty 2003, s. 249.
} 
nia się rozumna część jego natury ${ }^{4}$. Zdaniem Epikura, życie szczęśliwe to wolne od cierpienia, intensywnych rozkoszy ${ }^{5}$, bogate w przyjemności (hedone), otoczone błogim spokojem. Szkoła sceptyków wraz z Pirronem z Elidy i Sekstusem Empirykiem podaje, że stan szczęśliwości to obojętność na los oraz powściągliwość wobec problemu dobra, piękna i prawdy. Postawa obojętności zapewni spokój utożsamiony ze szczęściem ${ }^{6}$. Przedstawiciele myśli chrześcijańskiej, tacy jak Augustyn z Tagasty czy Tomasz z Akwinu, szczęście dostrzegali w zjednoczeniu człowieka z Bogiem-Absolutem ${ }^{7}$. Człowiek szczęśliwy to taki, który doznał łaski Bożej. Liczni przedstawiciele filozofia nowożytnej i jej myśliciele tacy jak J. J. Rousseau, J. Locke czy M. de Montaigne, odrzucali pochodzenie szczęścia od Boga-Absolutu, które ma charakter wieczny, na rzecz szczęścia ulotnego, subiektywnego, nacechowanego zadowoleniem, mającego swoje źródło w sferze ludzkich uczuć. Kartezjusz, G. Leibniz, B. Spinoza dostrzegali je w możliwości posiadania dóbr materialnych. J. Locke łączył je ze stanem zadowolenia ${ }^{8}$. Natomiast niemiecki filozof z Królewca I. Kant nie oddzielał przyjemności od szczęścia, twierdził, że nie ceniąc przyjemności, nie można też cenić szczęścia. Władysław Tatarkiewicz, jako przedstawiciel współczesnej szkoły filozoficznej, szczęście przeciwstawiał zadowoleniu czy przyjemności. Mówił o szczęściu nacechowanym głębią, trwałością oraz pewną całkowitością w swym istnieniu? .

Szczęście dotyczy wielu płaszczyznach życia ludzkiego. G. d' Azambuja w książce pod tytułem Szczęście doczesne. Krótka teoria szczęścia wymienia szczęście ogółu, szczęście społeczne oraz szczęście religijne.

Według tego myśliciela szczęście ogółu polega na zabezpieczeniu sobie jak największej sumy rozkoszy w sposób praktyczny, handlowy, za pomocą dobrze prowadzonej rachunkowości. W tym wszystkim należy mieć wzgląd na innych, otoczyć ich szacunkiem w celu utrzymania dobrych relacji międzyludzkich. Każdy, zanim przystąpi do jakiejkolwiek czynności, musi zapytać siebie, czy mu to przyniesie jakiś pożytek. W naszych działaniach należy uwzględnić rzeczy, które sprzyjają szczęściu: trwałość, pewność, intensywność czy płodność. Te wszystkie pierwiastki wiążą się nawzajem, tworząc pewne równanie matematyczne. W konsekwencji, pracując dla własnego dobra, pracujemy jednocześnie dla dobra ogółu. Pracując dla własnego interesu,

${ }^{4}$ Arystoteles, Etyka nikomachejska, 1177a 12-b 30, thum. D. Gromska, Warszawa 1956, s. 16-17.

5 G. d' Azambuja, Szczęście doczesne. Krótka teoria szczęścia, tłum. H. Romanowski, Warszawa 1909, s. 21.

${ }^{6}$ Diogenes Laertios, Żywoty i poglady..., Ks. IX, 90-93.

7 Tomasz z Akwinu, Summa teologiczna, Zag. 3, Art. 7, t. 9, (Cel ostateczny czyli szczęście oraz uczynki ludzkie), tłum. F.W. Bednarski, London 1995, s. 41.

${ }^{8}$ J. Locke, Rozważania dotyczace rozumu ludzkiego, t. I, thum. B.J. Gawecki, Warszawa 1955, s. $310-311$.

${ }^{9}$ W. Tatarkiewicz, O szczęściu, Warszawa 1962, s. 40. 
przyczyniamy się do ogólnego postępu ${ }^{10}$. Cały sens polega na tym, ,że zamiast czynić dobrze innym, pracując dla siebie, czyni się dobrze sobie, pracując dla innych"ll.

Na szczęście społeczne, które może być naszym udziałem, wpływają bez wątpienia potrzeby podstawowe, wspólne wszystkim ludziom: potrzeba picia, jedzenia, ubrania, schronienia (mieszkania), ale także trzeba zdobywania wiedzy czy rozrywki. Istnieją także potrzeby wyższego rzędu, np. wykształcenia czy wrażeń estetycznych, które podlegają temu samemu ogólnemu prawu. Do szczęścia niezbędne jest zaspokojenie tych wszystkich potrzeb, przeciwnie, brak zaspokojonych potrzeb jest przeszkodą do urzeczywistnienia szczęścia. A jest ono tym więcej niedoskonałe i tym ,więcej oddalone, im większą jest ilość i intensywność owych niezaspokojonych potrzeb"12, człowiek wtedy zostaje wystawiony na rozpacz i cierpienie.

Szczęście społeczne to także pewne minimum dóbr materialnych, pewien dostatek $^{13}$. Na szczęście wpłynie niezliczona liczba wynalazków, które umożliwią zdobycie środków do życia i wszelkich wygód bez większego trudu. Dzięki wynalazkom, będziemy mogli zadbać o nasze zdrowie, które jest bez wątpienia najwyższym dobrem i podstawą wszelkich innych dóbr w naszym życiu. Postęp dobrobytu materialnego ma doniosłość praktyczną.

Szczęście religijne to nie tylko szczęście pozagrobowe, ale także i w doczesnym życiu. Religia zawiera w sobie wiele pierwiastków, które przyczyniają się do uzyskania szczęścia: dodatnio wpływa na nasze zdrowie, wkładając obowiązek hamowania naszych namiętności, w chorobie i cierpieniu Bóg ulży naszemu jestestwu i napełni go wiarą przed nicością. Religia to także źródło rozkoszy, dzięki śpiewom i modlitwom w ekstazie można dostąpić zjednoczenia $z$ Bogiem ${ }^{14}$.

Po krótkim przedstawieniu filozoficznych koncepcji szczęścia oraz funkcjonowania tego fenomenu na różnych płaszczyznach życia ludzkiego, w niniejszej pracy pragnę przedstawić problem szczęścia zgodnie z traktatem O życiu szczęśliwym (De vita beata) według Seneki Młodszego. Celem moich badawczo-naukowych rozważań będzie krytyczna analiza zagadnień: życia zgodnego z naturą, cnoty, wolności oraz stosunku do dóbr materialnych (bo-

${ }^{10}$ G. d' Azambuja, Szczęście doczesne..., s. 25.

${ }^{11}$ Tamże, s. 27.

12 Tamże, s. 43.

${ }^{13}$ G. d' Azambuja podaje, że dobrobyt materialny będzie inaczej rozumiany przez zwyczajnego robotnika, inaczej natomiast przez przedstawiciela burżuazji. Robotnik zazna szczęścia dzięki wyższym zarobkom, mechanizacji pracy oraz skróceniu jej czasu. W wolnym czasie będzie oddawał się lekturze i uzupełniał swoje wykształcenie. Bogacz natomiast, szczęścia zazna, gdy będzie unikał rozkoszy, w ten sposób dbając o swoje zdrowie. Zechce się zająć pracą pożyteczną, pokładać szczęście własne w szczęściu innych, czyniąc im dobrze przy każdej sposobności. Tamże, s. 55.

${ }^{14}$ Tamże, s. 49-50. 
gactwa), które charakteryzują filozoficzną teorię szczęścia tegoż wybitnego filozofa starożytnego Rzymu.

\section{Na czym polega szczęście i jaką drogą je zdobyć według Seneki Młodszego}

\section{1) Życie zgodne z naturą}

Pośród najważniejszych składowych stoickiego systemu etycznego (a Seneka Młodszy był przedstawicielem tegoż systemu ${ }^{15}$ ) pojawia się fundamentalne pytanie: Jak żyć, aby osiągnąć szczęście? Pytanie to obejmuje zarówno indywidualne życie człowieka, jak i sferę życia społecznego.

Według stoików, życie indywidualne jest dobre, a więc szczęśliwe, jeśli jest zgodne $\mathrm{z}$ naturą, zgodne $\mathrm{z}$ samym sobą. Żyć zgodnie $\mathrm{z}$ naturą nie znaczy podążać za każdą skłonnością natury, ale żyć zgodnie z jej rozumną częścią, iść za wskazaniem rozumu. Rozum będzie najlepszym przewodnikiem, który doprowadzi człowieka do osiągnięcia owej niezachwianej harmonii z naturą ${ }^{16}$.

Seneka Młodszy w swym traktacie $O$ życiu szczęśliwym kładzie duży nacisk na znaczenie rozumu w funkcjonowaniu jednostki, twierdząc, że dzięki niemu człowiek wyprzedza zwierzęta i kroczy śladami bogów ${ }^{17}$. Doskonały więc rozum jest właściwym dobrem człowieka, wszystko inne ma on wspólne ze zwierzętami i roślinami. Ten antyczny, rzymski filozof-stoik o ludzkiej aktywności opartej na rozumie, co jest tożsame z byciem na właściwej drodze ku szczęściu, wypowiada się następująco:

O nikim bowiem nie można powiedzieć, że jest szczęśliwy, kto się znajduje poza granicą prawdy. Życie szczęśliwe to takie więc życie, które się zasadza na prawdzie i na niewzruszonej pewności sądu i nie podlega odmianom ${ }^{18}$. [...] szczęśliwy jest ten, komu każde położenie i warunki zaleca rozum ${ }^{19}$. Niech zawsze dochowa wierności raz powziętym przez się postanowieniom i nigdy ani na krok nie od-

${ }^{15}$ B. Inwood, Reading Seneca. Stoic Philosophy at Rome, Oxford 2005, s. 1.

${ }^{16}$ D. Budzanowska, Z rozważań Seneki o Bogu, „Seminare. Poszukiwania Naukowe”, nr 31, 2012, s. 212.

${ }^{17}$ L. Joachimowicz, Wstęp, w: L.A. Seneka, Dialogi, thum. L. Joachimowicz, Warszawa 1998, s. 41.

${ }^{18}$ L.A. Senecae, Opera, Friderigus Haase, vol. 1, Lipsiae, Sumptibus Et Typis B. G. Teubneri, 1852, s. 143. Tekst De vita beata znajduje się także w dziełach zebranych Seneki który jest dostępny w wersji elektronicznej (http://scans.library.utoronto.ca/pdf/9/31/operaquaesupers1v2sene/operaqu aesupers1v2sene.pdf) [dostęp: 05.09.2017]. Natomiast w przekładzie polskim: L.A. Seneka, O życiu szczęśliwym, tłum. L. Joachimowicz, Dialogi, Warszawa 1998, s. 164.

${ }^{19}$ L.A. Senecae, Opera..., s. 144; por także L.A. Seneka, $O \dot{z} y c i u \ldots$, s. 166. 
stępuje od raz uznanych zasad ${ }^{20}$. Niech rozum szuka prawdy, w duszy takiego człowieka panować będzie wzorowy ład i porządek ${ }^{21}$.

Zatem w myśli tegoż filozofa zawarta jest wskazówka, że jednostka, krocząca zgodnie $z$ warunkami i zasadami rozumu, nie znajdzie się poza granicą prawdy. Pomimo niesprzyjających okoliczności, szczęśliwy duch ten, który będzie posłuszny nakazom rozumu. Wielkie wytężenie woli zanurzonej w prawdzie, pozwoli osiągnąc harmonię i spokój, co jest tożsame ze zbliżeniem się ku drodze do szczęścia ${ }^{22}$.

Filozof w trakcie kontynuacji swojego wywodu na temat pojęcia szczęścia charakteryzuje kondycję czy stan ducha człowieka, który doznał szczęścia tymi słowami:

Życie szczęśliwe polega na tym, że duch jest wolny, wzniosły, nieustraszony, niezłomny, niedostępny dla lęku, niedostępny dla żądzy? Istnieje dla niego jedno dobro - prawość, jedno zło - nikczemność [...]. Na takich podstawach ugruntowanemu duchowi siłą konieczności towarzyszyć musi, [...] nieustająca wesołość i głęboka radość 23 .

W tych słowach dostrzegamy także rolę rozumu na drodze ku ziemskiemu szczęściu człowieka. Człowiek prawy jest jednocześnie dobry, zatem unika zła. A tylko rozum poprowadzi człowieka ku dobrym uczynkom. Dobre uczynki natomiast znajdą swoje ugruntowanie na silnych podstawach rozumu.

Świat-kosmos jest odzwierciedleniem absolutnego ładu, odwiecznie zadanej wewnętrznej harmonii oraz dyscypliny istnień we wzajemnych relacjach. Jest jednolitą uporządkowaną strukturą z wielkim łańcuchem bytów ${ }^{24}$, w której ma swoje miejsce wielość istnień. Doskonały kosmos jest jednością w nieustannej przemianie, wszelkie przeobrażenia podlegają jednemu, wiecznemu prawu, które jest wspólne dla materii ożywionej i nieożywionej. „Stałe są tylko relacje, a wszelkie przejawy życia podlegają ciągłej przemianie"25. Natura człowieka jest częścią składową natury wszechświata, a jego rozum częścią powszechnego rozumu boskiego, zatem żyć zgodnie z naturą, znaczy żyć zgodnie z ładem ustanowionym na świecie, z prawami natury, z odwiecznym Logosem ${ }^{26}$. Odejście od praw Logosu doprowadza do samozagłady, gdyż

${ }^{20}$ Tamże, s. 145; por. także tamże, s. 168.

${ }^{21}$ Tamże, s. 146; por. także tamże, s. 169.

${ }^{22}$ D. Budzanowska, Z rozważań..., s. 214.

${ }^{23}$ L.A. Senecae, Opera..., s. 142-143; por. także L.A. Seneka, $O \dot{z ̇ y c i u \ldots, ~ s . ~} 163$.

${ }^{24}$ A. Hajduk, Trzy aspekty ekologii Seneki $i$ św. Franciszka, w: Ekologia i społeczeństwo: Polityka i etyka wobec zagadnień ekologicznych, red. A. Delorme, Wrocław 2001, s. 56.

${ }^{25}$ Tamże, s. 58.

${ }^{26}$ L. Joachimowicz, Wstęp..., s. 41; por. także M. Aureliusz, Rozmyślania, II 17, tłum. M. Reiter, Warszawa 1988, s. 12. 
w ten sposób człowiek, stając ponad naturą, będzie działał jedynie na własną szkodę $^{27}$. W kontekście trwania jednostki zgodnego $\mathrm{z}$ samym sobą (swoim wnętrzem), ale także życia $\mathrm{w}$ symbiozie $\mathrm{z}$ otaczającym wszechświatem (także obcowanie z pierwiastkiem boskim) $)^{28}$, Seneka podaje, jak czytamy:

Zresztą, w czym wszyscy stoicy są zgodni, jestem uległy prawom natury. Nie zbłądzić z jej drogi, kształtować swe życie według jej prawa i wzoru - oto co znaczy mądrość. A zatem życie szczęśliwe jest to życie zgodne z naturą człowieka i tylko pod tym warunkiem może je ktoś osiągnąć, że dusza jest przede wszystkim zdrowa i trwa $\mathrm{w}$ nieprzerwanym posiadaniu tego zdrowia, $\mathrm{z}$ kolei - tryskająca energią i siłą, dalej - urzekająco hartowna w cierpieniu, przystosowana do wymagań czasu, troskliwa o ciało i sprawy z ciałem związane, ale - bez niepokoju, zabiegająca również o inne rzeczy, które są w życiu pomocne, ale - bez bałwochwalczego podziwu dla którejkolwiek, wreszcie - gotowa korzystać z dobrodziejstw losu, ale - bez zaprzedania im się w niewolę $e^{29}$.

Ludzkie trwanie polegające na wymianie materii $\mathrm{w}$ zgodzie $\mathrm{z}$ otaczającą przyrodą jest także otwartością na relację z Absolutem ${ }^{30}$, który przenika wszystko i rozumnie kieruje światem. Życie w symbiozie z wszechrzeczywistością zapewnia spokój, siłę i wytrwanie wśród trudów i przeciwności losu. W konsekwencji dla indywiduum funkcjonowanie według norm i nakazów rozumu prowadzi do najwyższego dobra, jakim jest szczęście. „Rozum jest dany po to, aby żyć w jeszcze większej harmonii ze wszystkim, co nas otacza"31.

\section{2) Cnota}

W życiu pojedynczego człowieka najwyższym, jedynym dobrem jest cnota $^{32}$. Żyć zgodnie z naturą oznacza tyle, co pozostawać zawsze w zgodzie

${ }^{27}$ A. Hajduk, Trzy aspekty..., s. 54.

${ }^{28}$ Seneka w kontekście relacji człowieka $\mathrm{z}$ boskim pierwiastkiem wypowiada się następująco: „Między ludźmi dobrymi i bogami istnieje przyjaźń, [...] istnieje związek, istnieje podobieństwo (similitudo), ponieważ człowiek dobry różni się od boga tylko czasem trwania, i jest jego uczniem, jego prawdziwym potomstwem”. W. Turek, Człowiek w obliczu cierpienia: „De providentia”' Seneki i „De mortalitate” Św. Cypriana, „Studia Płockie”, nr 24, 1996, s. 135.

${ }^{29}$ L.A. Senecae, Opera ..., s. 142; por także L.A. Seneka, O życiu..., s. 161-162.

${ }^{30} \mathrm{~W}$ kontekście podjęcia próby zbliżenia się człowieka do Boga jako bytu Seneka w swych Listach moralnych do Lucjusza podaje: „Bóg jest w pobliżu Ciebie, jest on $\mathrm{z}$ tobą, jest w tobie samym [...]. Obcuje wprawdzie $\mathrm{z}$ nami, lecz $\mathrm{w}$ istocie mocno się trzyma swego pochodzenia [...] L.A. Seneka, Listy moralne do Lucjusza, tłum. W. Kornatowski, Warszawa 1961, s. 1-5.

${ }^{31}$ A. Hajduk, Trzy aspekty..., s. 65.

${ }^{32}$ Rzymski stoik uważa, że cnota jest istotą żywą, czego dowodem jest jej wpływ na ludzkie ciało: daje żywość oczom oraz napięcie i skupienie. D. Budzanowska, Być roztropnym, czyli 
z cnotą, wszystkie zaś inne rzeczy odpowiadające naturze dobierać również według tego, czy nie sprzeciwiają się cnocie ${ }^{33}$. Cnota, pośród trudów życia, jako jedyna zapewnia szczęście i jednocześnie zabezpiecza przed katastrofą i wszelkimi egzystencjalnymi zachwianiami bez względu na okoliczności ${ }^{34}$. W stosunku do zagadnienia cnoty rozumianej jako fundamentalne dobro w życiu indywiduum Seneka stawia następujące pytanie: „Czemu raczej nie szukam jakiegoś dobra, z którego czułbym korzyść wewnętrzną, a nie błyszczał nim tylko na zewnątrz?" 35 . W kontekście tegoż pytania o ludzkie egzystencjalne doświadczenie wnioskuje on:

Te wszystkie dobra, na które ludzie patrzą z podziwem, przy których uważnie przystają, które jeden drugiemu ze zdumieniem wzajemnie wskazuje - świecą od zewnątrz przepychem, od wewnątrz nędzą ${ }^{36}$.

Seneka w dalszej części traktatu, analizując pojęcie cnoty, ponownie stawia egzystencjalne pytanie, by dowiedzieć się, co czynić i czego szukać. Filozof $w$ odpowiedzi podaje następujące zalecenie:

Szukajmy zatem jakiegoś dobra, nie takiego jednak, które mieni się pięknymi pozorami, ale trwałego i prawdziwego, od strony zaś bardziej ukrytej - tym wspanialszego ${ }^{37}$.

Tym trwałym, prawdziwym i wyłącznym dobrem jest cnota $^{38}$. Czyż zazwyczaj nie jest tak, że to co piękne, cenne i szlachetne w człowieku, nie jawi się nam tak nagle, ponieważ jest gdzieś głęboko ukryte $\mathrm{w}$ jego wnętrzu, natomiast to, co niewarte naszej uwagi, łatwo dostrzec, objąć zmysłami, bo błyszczy na zewnątrz? Filozof namawia do poszukiwań dobra (cnoty) trwałego w swej istocie, prawdziwego i rzadkiego w swej częstotliwości. Dobro, którego należy poszukiwać, ma za zadanie moralne uformowanie jednostki.

$\mathrm{W}$ trakcie swych filozoficznych dociekań nad pojęciem cnoty ten antyczny uczony wprowadza definicję najwyższego dobra, które ujmuje następująco:

przewidywać: Z myśli filozoficznej Seneki Młodszego o cnocie „prudentia”, „Colloquia Litteraria”, nr 1/2/8/9, 2010, s. 61; por. także W. Tatarkiewicz, Historia filozofii, t. I, Warszawa 2005, s. 148.

${ }^{33}$ L.A. Seneka, Myśli, tłum. S. Stabryła, Warszawa 1999, s. 12-13.

${ }^{34}$ D. Budzanowska, Seneka Mtodszy o bogactwie, „Kultura-Media-Teologia”, nr 6, 2011, s. 37.

${ }^{35}$ L.A. Senecae, Opera..., s. 141; por. także L.A. Seneka, $O \dot{z ̇ y c i u . . ., ~ s . ~} 160$.

${ }^{36} \mathrm{Z}$ org. łacińskiego: Ista, quae spectantur, ad quae consistitur, quae alter alteri stupens monstrat, foris nitent, introrsus misera sunt. L.A. Senecae, Opera..., s. 141.

${ }^{37}$ Tamże, s. 141; por także L.A. Seneka, $O$ życiu..., 161.

${ }^{38}$ M. Kostyra, Pojęcie cnoty w etyce Antystenesa z Aten, „Zeszyty Naukowe Towarzystwa Doktorantów UJ. Nauki Humanistyczne”, nr 2, 2011, s. 149. 
1) Najwyższym dobrem jest duch, który gardzi każdą rzeczą przygodną, a z samej cnoty czerpie radość.

2) Najwyższym dobrem jest niezwyciężona moc ducha, wypróbowana $\mathrm{w}$ ogniu doświadczeń, łagodna $\mathrm{w}$ działaniu, przepojona wielką miłością do ludzi i troską o tych, z którymi styka się w życiu ${ }^{39}$.

Najwyższym celem i dobrem człowieka jest szczęście, wyłącznym i wystarczającym do tego warunkiem jest cnota $^{40}$. Cnota jest jedna i niepodziel$\mathrm{na}^{41}$ : ,ani nie zmniejsza się, ani nie zwiększa, utrzymuje swą miarę zawsze"42, niezależnie od uciążliwości losu. Chociażby nawet została usunięta, cofnęła się w samą siebie, mimo wszystko zachowuje silnego i niewzruszonego ducha, wielką roztropność i niezachwianą sprawiedliwośćc ${ }^{43}$. Kto ma jedną, ma wszystkie ${ }^{44}$, gdyż pozostają w nierozerwalnym wzajemnym związku, są postacią jednej. Przekonanie o jedności cnoty Seneka rozumie jako pewną jedność w różnorodności form, które ona przybiera. Jest ona wyłącznym dobrem człowieka i odwrotnie - jedynym złem jest występek. Wszystko inne, co znajduje się pośrodku, pomiędzy tymi skrajnymi, nie jest ani dobre, ani złe, lecz obojętne. Rzeczy obojętne nie podlegają kategorii ni to dobra, ni zła, mają swoje określenie jako proegmena, a więc ze swej istoty są zbliżone do dobra, mają wyższość, pierwszeństwo, są warte starania, wyboru, uznania, słowem, przedstawiają pewną względną wartość. Proegmena obejmują takie dobra duszy jak talenty, edukacja, wiedza, kompetencje artystyczne i techniczne oraz ,takie

${ }^{39} \mathrm{Z}$ org. łacińskiego: Summum bonum est animus fortuita despiciens, virtute laetus, aut invicta vis animi, perita rerum, placida in actu cum humanitate multa et conversantium cura. L.A. Senecae, Opera..., s. 142.

${ }^{40}$ G. d' Azambuja, Szczęście doczesne..., s. 23.

${ }^{41}$ Według Seneki każda cnota ma stosowną miarę i rozmiar: „Omnis in modo est virtus; modo certa mensura est”, a jak cnoty są sobie równe, tak i czyny cnót oraz ludzie, którzy posiedli cnoty: „virtutes inter se pares sunt et opera virtutis et omnes homines quibus illae contigere”. D. Budzanowska, Temperantia, stoicki złoty środek według Seneki Młodszego, „Symbolae Philologorum Posnaniensium Graecae Et Latinae", nr XXI/2, 2011, s. 80.

${ }^{42}$ L.A. Seneka, Listy moralne..., s. 391.

${ }^{43}$ D. Budzanowska, Sprawiedliwość a władca w pismach filozoficznych Seneki, „VOX PATRUM”, t. 20,2000 , s. 555.

${ }^{44}$ Rzymski stoik podaje, że cnota jest tylko jedna, która na drodze intelektualnego wysiłku człowieka objawia się zależnie od potrzeb $\mathrm{w}$ wielu postaciach, formach czy jakościach. Do cnót głównych stoickiego systemu należy zaliczyć mądrość, umiarkowanie, męstwo oraz sprawiedliwość. Cnotom głównym podporządkowane są inne cnoty: mądrości - rozsądek, rozwaga, zaradność, wynalazczość, błyskotliwość; umiarkowaniu - skromność, opanowanie; męstwu odwaga, nieustraszoność, wytrzymałość, pracowitość; sprawiedliwości - uprzejmość, dobroć oraz towarzyskość. D. Budzanowska, Seneka Młodszy o cnocie męstwa - fortitudo, czyli o pokonywaniu strachu i cierpienia, „Słowo Krzyża. Rocznik poświęcony teologii krzyża oraz duchowości i historii pasjonistów", t. 3, 2009, s. 241. 
dobra ciała jak życie, zdrowie ${ }^{45}$, uroda, siła, i wreszcie zewnętrzne dobra fortuny, jak szlachetne urodzenie, sława imienia, bogactwo, godności, poważanie" ${ }^{46}$. Są to tzw. prima naturae, główne przedmioty wrodzonych potrzeb i dążeń natury ludzkiej. Natomiast drugą pozycję pośród tych rzeczy obojętnych, zewnętrznych, związanych z konwencjonalnym wymiarem życia człowieka zajmują apoproegmena, a więc rzeczy oddalone od dobra ${ }^{47}$. Nie przedstawiają one wartości, nie przyczyniają się do szczęścia i z natury człowiek ich unika, są to: śmierć, choroba, ubóstwo, niesława ${ }^{48}$. „Śmierć ${ }^{49}$ i życie, sława i niesława, cierpienie i rozkosz, bogactwo i ubóstwo; to wszystko na równi przypada ludziom dobrym i złym"50. Nie są to bowiem rzeczy ni piękne, ni brzydkie, nie są zatem ani dobre, ani złe.

Każdy człowiek według stoików obdarzony jest doskonałą wolnością. W jaki sposób to odczytać? Chodzi o to, by człowiek zdołał wydobyć się z ziemskich pożądań, które powstają w nas wskutek fałszywych wyobrażeń. Owej absolutnej wolności może dostąpić tylko mędrzec, który całkowicie jest panem samego siebie i panem swego losu, gdyż żadna siła zewnętrzna nie może mu wydrzeć jego cnoty $^{51}$. Dusza cnotliwa jest wolna nie tylko od ran nieszczęścia, ale także od jego „draśnięć” ${ }^{2}$. Wysiłek, poświęcenie i ciągła walka ze sobą samym, czyni człowieka cnotliwym i zarazem wolnym w jego codziennych zmaganiach.

W kontekście wolności jednostki, co jest tożsame z prowadzeniem życia cnotliwego, Seneka stawia filozoficzne pytanie: „Jaką nagrodę obiecuje ci cnota za tego rodzaju zadanie bojowe?"53. W odpowiedzi na to pytanie przedstawia następujące uzasadnienie w swoim traktacie:

Rzeczy niezmiernie wielkie i równe przymiotom boskim: w niczym nie doznasz przymusu, niczego nie będziesz potrzebował, staniesz się wolny, bezpieczny, nie-

${ }^{45}$ Filozof wysoko ocenia takie wartości jak dobry stan zdrowia. Podaje, że mędrzec, mając wątłe ciało lub straciwszy oko, oczywiście nadal będzie dobrze się miał, wiedząc, że ma w sobie coś silniejszego niż ciało, wolałby jednak być silnego ciała; będzie więc on znosił zły stan zdrowia, lecz dobrego będzie pragnął: „Et exilis corpore aut amisso oculo valebit, malet tamen sibi esse corporis robur, et hoc ita ut sciat esse aliud in se valentius; malam valetudinem tolerabit, bonam optabit". D. Budzanowska, Temperantia, stoicki..., s. 81.

${ }^{46}$ L. Joachimowicz, Wstęp..., s. 43.

${ }^{47}$ M. Kostyra, Pojęcie cnoty..., s. 149.

${ }^{48}$ D. Budzanowska, Temperantia, stoicki..., s. 78.

${ }^{49}$ I. Ziemiński, Obecność i nieobecność śmierci, „Etyka”, Nr 33, 2000, s. 20; por. także M. Bombik, Filozoficzne pojęcia śmierci, „Śląskie Studia Historyczno-Teologiczne”, t. 40, z. 2, 2007, s. 442.

${ }^{50}$ L. Joachimowicz, Wstęp..., s. 44.

${ }^{51}$ Seneka w swoich pismach często podaje, że cnoty należy się uczyć, cnota wymaga pracy. Doskonałym przewodnikiem i nauczycielem w tym zakresie niewątpliwie będzie filozof. D. Budzanowska, Seneka Młodszy o cnocie..., s. 256.

${ }^{52}$ G. d' Azambuja, Szczęście doczesne..., s. 24.

${ }^{53}$ L.A. Senecae, Opera..., s. 152; por. także L.A. Seneka, $O \dot{z} y c i u \ldots$, s. 181. 
dostępny dla szkody; żaden twój wysiłek nie pójdzie na marne, żadna przeszkoda nie stanie ci w drodze, wszystko ułoży ci się według twego życzenia, nie spotka cię nic przeciwnego, nic na przekór twemu pragnieniu i woli ${ }^{54}$.

Według Seneki człowiek uzyska wolność tylko wtedy, gdy wyzwoli się od takich afektów, jak: zawiść, pożądliwość, smutek i obawa ${ }^{55}$, które są przeszkodą na drodze jednostki ku wolności. Spokojny i wolny od takich doświadczeń, niczym niezmącony duch człowieka, żyjący w cnocie, zbliży się w ten sposób ku owemu szczęściu.

Seneka także ustosunkował się do rozkoszy, podając, że jest wynikiem niegodziwych i przelotnych popędów naszego ciała. W dniu, w którym ktoś dozna rozkoszy, dozna również cierpienia. Filozof podaje, iż wielkim nieszczęściem człowieka jest to, że władać nim będą rozkosz i ból, które są przyczyną wszelkiego zła. $Z$ tegoż poddaństwa trzeba wydostać się na wolność. Wyzwoleniem tym będzie obojętność na doświadczenia losu ${ }^{56}$ połączona ze skromnością i świadomością własnej nicości. Powszechnie wiadomo, że im kto głupszy, tym obficiej zaznaje rozkoszy. Nawet sama dusza dostarcza wielu niegodziwych rozkoszy, takich jak: rozrzutność, zbyt wysokie mniemanie o sobie, pycha, ślepe i nierozsądne umiłowanie własnych rzeczy, ale także gadulstwo, gnuśność i rozleniwienie ospałego ducha, opływającego w przyjemności i drzemiącego w sobie. Na te różnego rodzaju rozkosze cnota stanowić będzie najlepsze lekarstwo ${ }^{57}$. Otóż ona je wszystkie rozpędza, człowieka zaś targa za ucho: Haec omnia virtus discutit et aurem pervellit ${ }^{58}$. Seneka w podsumowaniu dodaje:

Zawsze niech cnota idzie przodem i ona niech niesie chorągiew, wcale mniej nie będziemy mieli przez to rozkoszy, ale staniemy się jej panami oraz władcami. Damy się w tym i owym uprosić - w niczym zniewolić. Ci natomiast, którzy pierwszeństwo i przewagę dali rozkoszy, wyzbywają się zarówno jednego, jak i drugiego ${ }^{59}$.

${ }^{54}$ Tamże, s. 152; por. także tamże, s. 181

${ }^{5} \mathrm{~W}$. Tyburski, A. Wachowiak, R. Wiśniewski, Historia filozofii i etyki do wspótczesności. Źródla i komentarze, Torun 2002, s. 106.

${ }^{56}$ L.A. Seneka, $O \dot{z} y c i u \ldots . .$, s. 164.

${ }^{57}$ D. Budzanowska, Temperantia, stoicki..., s. 84; por. także D. Budzanowska, Seneka Młodszy..., s. 48.

${ }^{58}$ Pliniusz Starszy w swych pismach filozoficznych o człowieku podaje, że ucho ludzkie jest siedliskiem pamięci: „est in aure ima memoriae locus” - tamże, s. 84.

${ }^{59}$ L.A. Senecae, Opera..., s. 150; por. także L.A. Seneka, O życiu..., s. 177. 


\section{3) Dobra materialne}

W trakcie swych rozważań nad istotą szczęścia i sposobu jego osiągnięcia filozof porusza także problematykę bogactwa czy posiadania znacznych dóbr materialnych. W możliwości posiadania tychże, jeśli zostały one zdobyte w sposób uczciwy ${ }^{60}$, nie dostrzega niczego niestosownego. Bogactwem należy się cieszyć i przyjmować je jako życzliwość losu. Seneka zastanawia się tylko nad różnicą, jaka zachodzi w sytuacji, gdy głupiec i mądry tak samo chce posiadać. Zauważa on ważną różnicę w tym przypadku, odpowiadając jasno i zdecydowanie. Uważa bowiem, że bogactwa u mądrego pozostają na służbie, u głupiego przy władzy. Mądry bogactwom nie zezwala na nic, głupiec - na wszystko $^{61}$. Człowiek opanowany chciwością posiadania rzeczy widzi świat jako zbiór niezależnych elementów. Dobra materialne postrzega przez pryzmat użyteczności czy praktycznego zastosowania. Pożądanie rzeczy zbędnych, w efekcie szkodliwych to odstąpienie od natury, co skutkuje zaprzedaniem ducha w niewolę ciała. „Bo zanikła już owa naturalna miara $\mathrm{w}$ zaspokajaniu koniecznych potrzeb, teraz już przejawem prostactwa i biedy jest chcieć tyle, ile potrzeba" ${ }^{2}$. W podsumowaniu Seneka dodaje, iż w szczęśliwym położeniu ,jest ten, co niczego nie pragnie"63. Filozof w traktacie wspomina o negatywnym wpływie bogactw na jednostkę. Jak czytamy:

[...] gnuśniejecie w swoich bogactwach i ani nie pomyślicie, ile nieszczęść zagraża zewsząd, które lada chwila mogą porwać wspaniałe łupy. Kto jednak mądremu zabierze bogactwa, zostawi mu całe jego mienie, będzie on bowiem żyć - wesoły z teraźniejszości, spokojny o przyszłość 64 !

W słowach filozofa zawarte jest przesłanie, zgodnie z którym człowiek nie powinien się zbytnio przyzwyczajać do swoich bogactw. Należy wręcz być obojętnym wobec nich, ponieważ w chwili, gdy je utracimy, nasz duch zbytnio się nie wzruszy. Dobra niezwykle szybko przemijają ${ }^{65}$, jednak człowiek wciąż troszczy się o nie, by go nie opuściły, przed tym niech chroni umiar, rozumne podejście do nich. Niech owa obojętność i niezależność zarazem, przyczyni się do tego, że żadna rzecz nie będzie miała nad nim władzy ${ }^{66}$.

${ }^{60}$ Seneka jako filozof, polityk, ale także właściciel i zarządca znacznych posiadłości i kapitału finansowego wysoko cenił dobra, które zostały zdobyte kłótnią z losem: „bona cum fortuna rixata” - D. Budzanowska, Seneka Młodszy o cnocie..., s. 252.

${ }^{61}$ Tamże, s. 197.

${ }^{62}$ L.A. Seneka, Listy moralne..., s. 424.

${ }^{63}$ G. d' Azambuja, Szczęście doczesne..., s. 23.

${ }^{64}$ L.A. Senecae, Opera ..., s. 161; por. także L.A. Seneka, O życiu..., s. 198.

${ }^{65}$ D. Budzanowska, Być roztropnym..., s. 64.

${ }^{66}$ D. Budzanowska, Temperantia, stoicki..., s. 83. 
Chętnie podejmę się trudów, niezależnie od tego, jakie są wielkie, i ciało swe będę wspierał siłą ducha. Będę w równej mierze gardził i tym bogactwem, które posiadam, i tym, którego mi braknie, i ani nie będę smutniejszy, jeśli należy do kogoś innego, ani dumniejszy, jeśli mnie otacza swym blaskiem. Nie wzruszę się ani wtedy, gdy szczęście się zbliży, ani wtedy, gdy się oddali ${ }^{67}$.

Seneka uważa, że mędrzec ,nie odtrąci od siebie życzliwości losu i nabytym godziwie spadkiem, ani nie będzie się pysznił, ani też nie będzie się go wstydził. Jednak również będzie się chlubił tym, że gdy otworzy dom i da dostęp całemu miastu do swego bogactwa, to będzie mógł powiedzieć każdemu, by jeśli coś rozpozna jako swoje, wziął to"68.

Ten rzymski uczony dostrzega bardzo ważny element o znaczeniu moralnym. Posiadanie znacznych bogactw, które nazywa darami losu, łączy z możliwością kształtowania charakteru osobowego człowieka. Bogactwa w swej specyfice (uwalniają od pracy, sprzyjając w ten sposób lenistwu) stwarzają możliwość, by jednostka mogła utwierdzić się w cnotach: pracowitości, staranności, gospodarności czy umiarkowania. Seneka podaje, że mędrzec, mając możliwości posiadania cennych rzeczy, bez lęku i strachu wystawi swoje cnoty na próbę, aby wzmocnić zachowanić harmonię wewnętrznego ducha, nie ulegając $\mathrm{w}$ ten sposób pokusom. Na koniec przypomina:

Mędrzec nie uważa siebie za niegodnego wszelkich darów losu: nie kocha bogactw, ale im daje pierwszeństwo, i przyjmuje je nie do duszy, ale do domu, i nie odrzuca tych, które posiada, ale je zachowuje i chce swojej cnocie dostarczyć więcej sposobności do próby ${ }^{69}$.

Społeczeństwo w myśli stoickiej jest organicznym zespołem ludzkim i każdy człowiek ma pewne obowiązki wobec tego zespołu. Komórka społeczna charakteryzuje się pewnym wymiarem braterstwa ze światem poza-nami. Ludzkie funkcjonowanie zgodne $\mathrm{z}$ ustanowionym, odwiecznym porządkiem wyraża braterski stosunek do otaczającego wszechświata, ale także staje się podstawą relacji społecznych w ogóle, a przez to całego świata stworzone$\mathrm{go}^{70}$. Człowiek, który nie podąża za wskazaniem rozumu, zakłóca naturalny porządek, burzy ład świata, a skutki tego ponoszą wszyscy. Powinnością jednostki na drodze intelektualnego wysiłku jest przeciwdziałanie naruszeniu pewnego zastanego systemu, całościowej równowagi wszechświata, co skutkuje także poprawnością relacji międzyludzkich. Wszelka wytwórczość homo

\footnotetext{
${ }^{67}$ L.A. Senecae, Opera $\ldots$, s. 155; por. także L.A. Seneka, $O \dot{z} y c i u \ldots$, s. 186.

${ }^{68}$ D. Budzanowska, Seneka Młodszy..., s. 43.

${ }^{69}$ L.A. Senecae, Opera..., s. 156; por. także L.A. Seneka, O życiu..., s. 189.

${ }^{70}$ L.A. Seneka, Listy moralne..., s. 51-53.
} 
faber jest możliwa wyłącznie dzięki mocy zawartej w naturze. Homo faber będzie aktywny tylko wtedy, gdy zezwoli mu na to natura ${ }^{71}$. Jednostka to także angażowanie się w życie publiczne, gdyż może to stanowić okazję do wykazania się swoją wiedzą, męstwem, odpowiedzialnością, sprawiedliwością, które to wpisują się w cnotliwe działanie człowieka.

$* * *$

Ludzka aktywność powinna wzorować się na naturze, pnieważ jest ona rozumna, harmonijna i boska. Człowiek będzie się doskonalił, gdy dostosuje się do powszechnej harmonii świata. W ten sposób zrozumie konieczność, którą niesie ze sobą świat. Natura samego człowieka jest także rozumna. Życie jednostki ma więc być zgodne $\mathrm{z}$ naturą $\mathrm{w}$ dwojakim sensie: $\mathrm{z}$ naturą wszechświata oraz z rozumną naturą własną. Wolność jednostki tkwi w świecie spraw od nas zależnych, np. obojętności wobec przelotnych popędów naszego ciała czy wobec blasku pięknych przedmiotów. Jest to wolność wystarczająca, a nawet olbrzymia. Trzeba więc zabiegać tylko o dobra wewnętrzne, doskonalić się duchowo i nie myśleć, że wolność tkwi w czymś poza nami. Na tym polega cnota. Cnota jest jedna i niestopniowalna, jest czystym dobrem, natomiast absolutnym złem jest życie wbrew niej. Cnota pomoże nam zbliżyć się do tej ścieżki prowadzącej ku upragnionemu szczęściu.

\section{THE QUESTION OF THE ESSENCE OF HAPPINESS AND THE METHOD TO OBTAIN IT IN THE TREATISE "ON THE HAPPY LIFE" BY SENECA THE YOUNGER}

\section{Summary}

The paper discusses the question of happiness according to the treatise "On the Happy Life" by Seneca the Younger. The world-cosmos, thus all that surrounds us, is of rational and divine character. All that exists and happens in the universe is due to necessity, some form of fate. The meaning and goal of human existence is a happy life, in harmony with nature, i.e. divine Logos, immersed in the universe. For Seneca, to live in harmony with nature means to live in harmony with Logos, his rational laws, and principles. The rational Logos will tell the human what is good and what is evil. The highest, one and true good of a human, worth striving for, is virtue. It is what a man should aim for. By following virtue, the human will act rationally, will be free

\footnotetext{
${ }^{71}$ A. Hajduk, Trzy aspekty..., s. 65.
} 
and unmovable in the face of all adversities. The virtue will facilitate reaching the desired happiness.

Słowa kluczowe: Seneka Młodszy; stoicyzm; rozum; cnota; szczęście

Keywords: Seneca the Younger; stoicism; reason; virtue; happiness

\section{BIBLIOGRAFIA}

Arystoteles, Etyka nikomachejska, 1177a 12-b 30, tłum. D. Gromska, Warszawa 1956.

Aureliusz M., Rozmyślania, II 17, thum. M. Reiter, Warszawa 1988.

Azambuja G., Szczęście doczesne. Krótka teoria szczęścia, thum. H. Romanowski, Warszawa 1909.

Bombik M., Filozoficzne pojęcia śmierci, „Śląskie Studia Historyczno-Teologiczne”, t. 40, z. 2, 2007, s. 441-449.

Budzanowska D., Być roztropnym, czyli przewidywać: Z myśli filozoficznej Seneki Młodszego o cnocie ,prudentia”, „Colloquia Litteraria”, nr 1/2/8/9, 2010, s. 51-77.

Budzanowska D., Seneka Młodszy o bogactwie, „Kultura-Media-Teologia”, nr 6, 2011, s. 37-52.

Budzanowska D., Seneka Młodszy o cnocie męstwa - fortitudo, czyli o pokonywaniu strachu i cierpienia, „Słowo Krzyża. Rocznik poświęcony teologii krzyża oraz duchowości i historii pasjonistów”, t. 3, 2009, s. 234-261.

Budzanowska D., Sprawiedliwość a władca w pismach filozoficznych Seneki, „VOX PATRUM”, t. 20, 2000, s. 553-560.

Budzanowska D., Temperantia, stoicki złoty środek według Seneki Młodszego, „Symbolae Philologorum Posnaniensium Graecae Et Latinae", nr XXI/2, 2011, s. 63-93.

Budzanowska D., Z rozważań Seneki o Bogu, „Seminare. Poszukiwania Naukowe”, nr 31, 2012, s. 207-219.

Delorme A., Ekologia i społeczeństwo: Polityka i etyka wobec zagadnień ekologicznych, Wrocław 2001.

Diogenes Laertios, Żywoty i poglądy stynnych filozofów, ks. II, 5, 18, tłum. I. Krońska, Warszawa 1982.

Hajduk A., Trzy aspekty ekologii Seneki i św. Franciszka, w: Ekologia i spoleczeństwo: Polityka i etyka wobec zagadnień ekologicznych, red. A. Delorme, Wrocław 2001, s. 53-69.

Inwood B., Reading Seneca. Stoic Philosophy at Rome, Oxford 2005.

Joachimowicz L., Wstęp, w: L.A. Seneka, Dialogi, thum. L. Joachimowicz, Warszawa 1998.

Kostyra M., Pojęcie cnoty w etyce Antystenesa z Aten, „Zeszyty Naukowe Towarzystwa Doktorantów UJ. Nauki Humanistyczne", nr 2, 2011, s. 133-151.

Locke J., Rozważania dotyczące rozumu ludzkiego, t. I, tłum. B. J. Gawecki, Warszawa 1955.

Platon, Eutydem, 280b-281e, thum. W. Witwicki, Dialogi, t. II, Kęty 2005.

Platon, Państwo, 540a-b, tłum. W. Witwicki, Kęty 2003.

Seneka L.A., Dialogi, tłum. L. Joachimowicz, Warszawa 1998.

Seneka L.A., Listy moralne do Lucjusza, tłum. W. Kornatowski, Warszawa 1961.

Seneka L.A., Myśli, tłum. S. Stabryła, Warszawa 1999.

Senecae L.A., Opera, Friderigus Haase, vol. 1, Lipsiae, Sumptibus Et Typis B. G. Teubneri, 1852.

Seneka L.A., O życiu szczęśliwym, tłum. L. Joachimowicz, Dialogi, Warszawa 1998.

Tomasz z Akwinu, Summa teologiczna, Zag. 3, Art. 7, t. 9, (Cel ostateczny czyli szczęście oraz uczynki ludzkie), thum. F. W. Bednarski, London 1995.

Tatarkiewicz W., Historia filozofii, t. I, Warszawa 2005.

Tatarkiewicz W., O szczęściu, Warszawa 1962. 
Tyburski W., Wachowiak A., Wiśniewski R., Historia filozofii i etyki do współczesności. Źródła i komentarze, Toruń 2002.

Turek W., Czlowiek w obliczu cierpienia: „De Providentia”'Seneki i „,De moratalitate”'Św. Cypriana, „Studia Płockie”, nr 24, 1996, 133-142.

Ziemiński I., Obecność i nieobecność śmierci, „Etyka”, nr 33, 2000, s. 9-28.

\section{ŹRÓDŁA INTERNETOWE}

http://scans.library.utoronto.ca/pdf/9/31/operaquaesupers1v2sene/operaquaesupers1v2sene.pdf) [dostęp 05.09.2017].

Joanna Picewicz, doktorantka na Wydziale Filozoficznym Akademii Ignatianum w Krakowie. Studia magisterskie na kierunku Pedagogika o specjalizacji edukacja filozoficzno-społeczna na Wydziale Etnologii i Nauk o Edukacji Uniwersytetu Śląskiego w Katowicach oraz podyplomowe z zakresu Historii na Wydziale Historycznym Uniwersytetu Jagiellońskiego w Krakowie. Dziedziny/zagadnienia zainteresowań naukowych: etyka, bioetyka, filozofia kultury, filozofia rzymska, prawa człowieka, katolicka nauka społeczna, filozofia wychowania i historia wychowania. Autorka artykułów naukowych z zakresu filozofii: Dylematy etyczne wokól definicji śmierci mózgowej, „Edukacja Filozoficzna”, 62, (2016) /2, Instytut Filozofii, Uniwersytet Warszawski, Warszawa ISSN 0860-3839, Zagadnienie transplantacji $w$ dokumentach społecznej nauki Kościoła, „Rocznik Filozoficzny Ignatianum", XXI, (2015) /1, Instytut Filozofii, Wydział Filozoficzny, Akademia Ignatianum w Krakowie, Kraków ISSN 2300-1402. Uczestniczka licznych konferencji gdzie przedstawia swoje aktualne badania naukowe. j.picewicz. filozofia@gmail.com 